\title{
Survival and degradation of Salmonella enterica serotype Enteritidis in intestinal epithelial cells in vitro
}

\author{
MARJA SAARINEN, L. J. PELLINIEMI* and KAISA GRANFORS \\ National Public Health Institute, Department in Turku and *Laboratory of Electron Microscopy, University of \\ Turku, Turku, Finland
}

\begin{abstract}
The survival and fate of Salmonella enterica serotype Enteritidis in Henle-407 human intestinal epithelial cells was investigated during prolonged incubation to evaluate the persistence of causative microbes and the relationship to patients developing reactive arthritis. Most of the bacteria were killed and degraded quite soon after infection of the cells, but there were still live bacteria inside the cells for up to 14 days. These results suggest that in patients developing reactive arthritis the salmonellae could persist in the epithelial cells and spread within the host to the joint and be present there at the time of the inflammatory response. Production of marked amounts of nitric oxide was observed as a novel response to salmonella infection in human intestinal epithelial cells. The present experimental procedure appears to be a suitable model to further investigate host-bacteria interaction in HLA-B27 positive cells from patients developing reactive arthritis.
\end{abstract}

\section{Introduction}

Salmonellae are facultatively intracellular pathogens both in man and animals [1]. They can cause disease ranging from gastroenteritis to typhoid fever, depending on the serotype of the bacteria. Animals are the main source of salmonellae although person-to-person spread does occur.

In the disease process, bacteria have to invade the intestinal epithelium, from which they can move to the Peyer's patches and further into the host. Several distinct loci have been reported to be involved in invasion by salmonellae [2-6]. However, the exact mechanism by which salmonellae invade the epithelial cells is still unknown. Salmonellae invade the intestinal epithelial cells typically in the distal ileum. Invasion is obviously a two-stage process consisting of adhesion followed by penetration. This has been concluded from observation that mutations in certain genes involved in invasion reduce the capacity of salmonellae to penetrate intestinal epithelial cells without affecting adhesion [5,7]. In the areas where Salmonella enterica serotype Typhimurium interacts

Received 30 Jan. 1996; revised version accepted 24 May 1996.

Corresponding author: Dr M. Saarinen. with the host cell, the morphology of the host cell changes remarkably $[8-10]$. The plasma membrane forms ruffles, which facilitate the uptake of particles to the cell, and the entry of salmonellae into cultured cells results from the intimate interaction of the cells and the bacteria [11]. The bacteria penetrating the epithelial cells are enclosed into vacuoles, and low $\mathrm{pH}$ appears to play a role in killing the bacteria. However, Salmonella spp. have been reported to live in epithelial cells up to $24 \mathrm{~h}[12,13]$.

Another possible factor which may play a role in the killing of intracellular bacteria in epithelial cells is nitric oxide (NO). It is an unstable, gaseous radical. Many cell types produce it either constitutively or as a consequence of certain stimuli, e.g., TNF, IFN- $\alpha,-\beta$ and $-\gamma$, IL-1 and IL-6, endotoxins, leishmania, mycobacteria, many viruses and parasites [14-16]. NO has been shown to play a role in several responses of the body, including vasodilatation, neurotransmission and immune and inflammatory reactions [17-20]. Increased NO synthesis has been reported in the mucosa of patients with ulcerative colitis $[21,22]$, and also epithelial cells in paranasal sinuses produce marked amounts of NO [23]. There has been no report of production of NO by human intestinal epithelial cells.

Some patients with salmonella enteritis develop 
reactive arthritis, usually $1-3$ weeks after the onset of the initial infection [24]. It is an asymmetric, nonpurulent polyarthritis and can vary from slight arthralgia to severe, disabling disease. Most patients with reactive arthritis have tissue antigen HLA-B27 [25]. The pathogenesis of reactive arthritis is unclear despite intensive investigation. However, persistence of causative microbes or parts of them seems to have an" important role in initiating and maintaining the disease [26].

As a first step towards the study of microbe-host interaction in reactive arthritis, a model was developed to observe intracellular life and degradation of $S$. enterica serotype Enteritidis during prolonged incubation in cultured intestinal epithelial cells.

\section{Materials and methods}

\section{Bacterial strains and culture conditions}

The strain of $S$. enterica serotype Enteritidis used in this study was a stool isolate from a patient with salmonella-triggered reactive arthritis. Invasive Escherichia coli (EIEC 3549; Central Public Health Laboratory, 61 Colindale Avenue, London) was also used in some experiments. Stock cultures were maintained at $-40^{\circ} \mathrm{C}$ in Trypticase soy broth with glycerol $20 \% \mathrm{v} / \mathrm{v}$. One day before adhesion or invasion assay, salmonellae were washed twice with PBS and incubated in LuriaBertani (LB) broth for $18 \mathrm{~h}$ at $37^{\circ} \mathrm{C} ; 0.5 \mathrm{ml}$ of this bacterial culture was added to $10 \mathrm{ml}$ of fresh prewarmed LB broth and incubated for a further $2 \mathrm{~h}$ at $37^{\circ} \mathrm{C}$ so that the bacteria were in logarithmic phase when they were used to infect the cells. E. coli were grown overnight at $37^{\circ} \mathrm{C}$ with vigorous shaking (200 rpm), and $0.5 \mathrm{ml}$ of the bacterial culture was added to $50 \mathrm{ml}$ of pre-warmed LB broth and incubated for a further $2 \mathrm{~h}$ at $37^{\circ} \mathrm{C}$ before infecting the cells.

\section{Cell cultures}

The cell line used in this study was Henle-407 (CCL-6; American Type Culture Collection, Rockville, MD, USA) which was derived from human embryonic jejunum and ileum. The cells were cultured in disposable dishes (Costar, Cambridge, MA, USA) and flasks (Greiner, Frickenhausen, Germany). The cells were grown in RPMI 1640 culture medium containing heat-inactivated fetal calf serum (FCS; PAA Laboratories, USA) $10 \% \mathrm{v} / \mathrm{v}$ and L-glutamine $(29.2 \mathrm{mg} / \mathrm{ml}$; Biological Industries, Kibbutz Beth Haemek, Israel) $1 \% \mathrm{w} / \mathrm{v}$ supplemented with $(/ \mathrm{ml})$ penicillin $10000 \mathrm{U}$, streptomycin $10 \mathrm{mg}$ and gentamicin $50 \mu \mathrm{g}$, (Biological Industries, Israel) at $37^{\circ} \mathrm{C}$ in air with $\mathrm{CO}_{2} 5 \%$ and $95 \%$ humidity in a $\mathrm{CO}_{2}$ incubator. For adhesion and invasion assays, cells were seeded in to $50-\mathrm{ml}$ flasks or six-well tissue culture plates and grown to confluency.

\section{Adhesion assay}

Confluent monolayers of Henle-407 cells were rinsed twice with pre-warmed Hank's Balanced Salts Solution (HBSS) to remove residual antibiotics and serum components. Cells were overlaid with pre-warmed RPMI culture medium supplemented with heat-inactivated human $\mathrm{AB}$ serum (Finnish Red Cross) 10\% v/v. It has been shown that chloramphenicol, an inhibitor of protein synthesis, reduces the invasion of $S$. Typhimurium to background levels [27]. So, to prevent penetration of the bacteria to the cells, chloramphenicol $40 \mu \mathrm{g} / \mathrm{ml}$ was added to the bacterial culture $30 \mathrm{~min}$ before infecting the cells with the bacteria. Bacterial inoculum (c. $70 \mathrm{cfu} / \mathrm{cell}$ ) was added, and the infected cells were incubated at $37^{\circ} \mathrm{C}$ for $2 \mathrm{~h}$ in a $\mathrm{CO}_{2}$ incubator. Cells were washed five times with HEPESbuffered HBSS to remove non-adherent bacteria. The cells were harvested by incubating the flasks in prewarmed EDTA (Sigma, $5 \mathrm{mmol} / \mathrm{L}$ ) in $\mathrm{Ca}^{2+}$, $\mathrm{Mg}^{2+}$-free HBSS for $10 \mathrm{~min}$ and by scraping the plates with a 'rubber policeman'. Cells were counted and the viability of the cells was estimated by Trypan Blue dye exclusion. Cells $\left(2 \times 10^{5}\right)$ were lysed with $1 \mathrm{ml}$ of distilled water to release intracellular bacteria, and washed once. LB broth $(1 \mathrm{ml})$ was added and a series of 1 in 10 dilutions was made. From each dilution a $100-\mu 1$ sample was plated on LB agar. The plates were incubated at $37^{\circ} \mathrm{C}$ overnight, the bacterial colonies on the plates were counted and the numbers of cfu were determined.

\section{Invasion assay}

The bacterial inocula were added to confluent cell monolayers as described above for the adhesion assay. Infected cells were incubated at $37^{\circ} \mathrm{C}$ for $2 \mathrm{~h}$ in a $\mathrm{CO}_{2}$ incubator and were then washed five times to remove non-adherent bacteria. Incubation was continued for different periods of time ( $1 \mathrm{~h}$ or $1,3,7$ or 14 days) in RPMI culture medium containing FCS $10 \% \mathrm{v} / \mathrm{v}$ and Lglutamine $1 \% \mathrm{w} / \mathrm{v}$ and supplemented with penicillin, streptomycin and gentamicin. Cells were harvested and counted and the viability of the cells was determined. Bacteria were released by the lysis of $2 \times 10^{5}$ cells, and the numbers of cfu were determined as described for the adhesion assay.

\section{Immunocytochemistry}

Henle-407 cells which were infected with $S$. Enteritidis and incubated for different periods ( $1 \mathrm{~h}-14$ days) were cytocentrifuged on to microscopic slides (50000 cells/ slide), air dried, and fixed with cold acetic acid/ethanol $5 \% / 95 \% \mathrm{v} / \mathrm{v}$ at $-20^{\circ} \mathrm{C}$ for $10 \mathrm{~min}$. Slides were then stored at $-20^{\circ} \mathrm{C}$ until used. Antisera against $S$. Enteritidis were raised by immunisation of rabbits with heat-killed $\left(100^{\circ} \mathrm{C}, 1 \mathrm{~h}\right)$ bacteria [28]. Increasing amounts of bacteria $(0.25,0.5,1.0,1.5$ and $2.0 \mathrm{ml}$ of bacterial suspension containing $c .10^{9} \mathrm{cfu} / \mathrm{ml}$ in phosphate-buffered saline) were injected into the rabbits 
intravenously once a week for 5 weeks. The animals were bled 1 week after the final injection. For immunocytochemical detection of bacteria, the slides with cells on were overlaid with antiserum diluted 1 in 100 in PBS containing bovine serum albumin (BSA; fraction $\mathrm{V}$; INC Biomedicals Ltd, Buckinghamshire) $0.2 \%$ (mixture designated BSA-PBS) and incubated at room temperature for $30 \mathrm{~min}$. The slides were washed three times with BSA-PBS and treated with fluoresceinated $\mathrm{F}\left(\mathrm{ab}^{\prime}\right)_{2}$ fragments of anti-rabbit immunoglobulin $\mathrm{G}$ (1 in 200) (Sigma) at room temperature for $30 \mathrm{~min}$. After three washes, the slides were dried, mounted with PBS-glycerol (1:9 v:v) which contained p-phelylenediamine (Sigma) $1 \mathrm{mg} / \mathrm{ml}$, and examined with an incident light-fluorescence microscope (Dialux 20; Leitz, Wetzlar, Germany) with an Osram HBO $100 \mathrm{~W}$ mercury lamp.

\section{Electrophoresis and immunoblotting}

The cell samples from different time points $(1 \mathrm{~h}-14$ days) were dissolved in Laemmli's sample buffer under mild reducing conditions ( $\beta$-mercaptoethanol $0.1 \%$ ) [29] and separated by vertical SDS-PAGE with a stacking gel of acrylamide $5 \%$ and a resolving-gradient gel of acrylamide $5-17 \%$. Standards of known mol.wt were included in each gel run (Rainbow protein mol. wt markers; Amersham). Western blotting was performed by a modification of the method of Towbin et al. [30]. The separated components in the gel were immediately transferred electrophoretically on to nitrocellulose sheets (pore size, $0.2 \mu \mathrm{m}$; Schleicher and Schuell, Dassel, Germany) by a Transphor apparatus (LKBBromma, Bromma, Sweden) with prechilled Trisglycine buffer $(\mathrm{pH} 8.3)$ at $0.041 \mathrm{~A}$ for $2.75 \mathrm{~h}$. The nitrocellulose sheets were cut into strips, and nonspecific binding sites were blocked by incubation in PBS containing non-fat milk $1 \% \mathrm{v} / \mathrm{v}$ at room temperature for $1 \mathrm{~h}$. After three washes with PBS, the strips were allowed to react overnight at $4^{\circ} \mathrm{C}$ with rabbit antiserum diluted 1 in 500 in PBS. The strips were then washed and incubated at room temperature for $3 \mathrm{~h}$ with peroxidase-conjugated anti-rabbit antibodies diluted 1 in 1000 in PBS with $\mathrm{AB}$ serum (Finnish Red Cross) $3 \% \mathrm{v} / \mathrm{v}$. After three washes, the reactions were developed with dioctyl sulphosuccinate substrate (Sigma) [31].

\section{Nitrite assay}

Nitrite concentration in the medium was measured by a Griess reagent method [32]. Supernates from different time points $(1 \mathrm{~h}-14$ days) after the epithelial cells were infected with bacteria were collected. Samples were mixed with equal volumes of Griess reagent (1:1 mixture of naphthylethylenediamine dihydrochloride $0.1 \% \mathrm{w} / \mathrm{v}$ and sulfanilamide $1 \% \mathrm{w} / \mathrm{v}$ in phosphoric acid $5 \% \mathrm{v} / \mathrm{v}$ and incubated for $10 \mathrm{~min}$ at room temperature. Absorbances at $546 \mathrm{~nm}$ were measured and nitrite concentrations were interpolated from reference standard curves prepared with sodium nitrite.

\section{Transmission electron microscopy}

Cells were harvested after $1 \mathrm{~h}, 1$ day and 3 days as described above and $2 \times 10^{4}$ cells/tube were centrifuged and fixed with glutaraldehyde (Merck, Darmstadt, Germany) $5 \%$ in $0.16 \mathrm{M}$ s-collidine buffer ( $\mathrm{pH}$ 7.4) and post-fixed with potassium ferrocyanideosmium fixative. The samples were embedded in epoxy resin (Glycidether 100, Merck) and then sectioned on a Reichert Ultracut E ultramicrotome (Reichert-Jung; Switzerland) for light and electron microscopy. Ultrathin sections were stained with uranyl acetate $12.5 \%$ and lead citrate $0.25 \% \mathrm{w} / \mathrm{v}$ and examined in a JEM100SX electron microscope (JEOL, Tokyo, Japan). For light microscopy, $1 \mu \mathrm{m}$ thick sections were cut and stained with toluidine blue $0.5 \%$.

\section{Statistical analysis}

To compare the bacterial recovery values at $1 \mathrm{~h}$ to later time points, Student's $t$ test was applied.

\section{Results}

\section{Viability of the cells}

At the early time points (adhesion and $1 \mathrm{~h}$ ) the cells were structurally normal and $90 \%$ of the cells were viable; the average number of viable cells was $2.0 \times 10^{6}$ cells/flask in the beginning and increased to $5.0 \times 10^{6}$ cells/flask at 3 days. Thereafter, the number of viable cells started to decrease as their relative proportion in the cell culture diminished (on average $1.5 \times 10^{6}$ viable cells/flask at 14 days), and the cells became more granular.

\section{Adhesion and invasion of the bacteria to epithelial cells}

$S$. Enteritidis adhered well to Henle-407 cells. The inoculum was $c .70 \mathrm{cfu} / \mathrm{cell}$, and $0.1-0.4 \mathrm{cfu} / \mathrm{cell}$ were attached to the surface (Fig. 1). When examined by fluorescence microscopy many bacteria adhered to the surface of some cells, whereas no bacteria could be seen attached to the others. A similar phenomenon was noticed in invasion; some cells were invaded by several bacteria, while in others bacteria could not be seen. The number of invading bacteria at $1 \mathrm{~h}$ was usually $1-$ $3 \mathrm{cfu} / \mathrm{cell}$.

\section{Survival of bacteria in epithelial cells}

The fate of $S$. Enteritidis in human intestinal epithelial cells was followed for 14 days. The number of live bacteria/cell diminished quite steadily from 0.01 to $0.2 \mathrm{cfu} /$ cell at 1 day $(\mathrm{p}=0.02$, compared with $1 \mathrm{~h})$ to $0.001-0.2 \mathrm{cfu} / \mathrm{cell}$ at 3 days $(\mathrm{p}=0.005)$ and 7 days 
$(p=0.02)$ (Fig. 1). Even after incubation for 14 days, there was still growth of $0.0005-0.1 \mathrm{cfu} / \mathrm{cell}$, $\mathrm{p}=0.005$ ), indicating live bacteria in the cells. The number of viable bacteria/flask varied from a maximum of $5.0 \times 10^{6} \mathrm{cfu} / \mathrm{flask}$ at the earlier time points to an average of $1.2 \times 10^{6} \mathrm{cfu} /$ flask at 14 days. One experiment was also made with invasive $E$. coli strain for up to 8 days. At 1 day the number of intracellular bacteria was the same as the salmonella, and at 8 days the number of live bacteria/cell was 0.005 (data not shown).

\section{Degradation of bacteria in epithelial cells}

Immunocytochemical detection of $S$. Enteritidis in infected epithelial cells after $1 \mathrm{~h}$ of infection showed that most of the bacteria within the cells were intact, but in some the outer wall was ruffled and the shape of many bacteria had become more globular (Fig. 2). At 1 day the cells contained only ghosts of the bacteria, and hardly any intact bacteria were seen. Large accumulations of degraded material and tiny positive dots were detected within and outside the cells. From 3 days until 14 days the amount of dense, clearly positive material within the cells diminished and tiny dots disappeared gradually.

Immunoblotting demonstrated a clear difference between the sample of whole bacteria and samples of infected cells; much of the bacterial material disappeared from cell samples. Also, many of the bands (between 20 and $40 \mathrm{kDa}$ ) which could be seen clearly in the strips at $1 \mathrm{~h}$ had either disappeared or become weaker at later time points (Fig. 3). Rabbit antiserum reacts clearly with O-polysaccharide of LPS of salmonellae, and the typical ladder pattern of this structure had lost intensity already in the strips of the early time points. Although continuous degradation of bacterial material could be seen, antigens recognised by the antibody were still visible at 14 days.

\section{NO production by infected epithelial cells}

Incubation media from infected cells were collected at different time points $(1 \mathrm{~h}, 3 \mathrm{~h}$ and 1, 2, 3, 4, 5 and 6 days) and nitrite, a stable oxidation product of $\mathrm{NO}$, was measured with Griess reagent. Already at the beginning of infection (after $1 \mathrm{~h}$ ) the production of nitrite by infected cells was slightly higher than the production by uninfected control cells (Fig. 4). Production increased up to 2 days, after which it began to diminish again.

\section{Transmission electron microscopy}

Ultrastructural analysis of Henle-407 cells in control cultures (Fig. 5) and in those infected with $S$. Enteritidis confirmed the immunofluorescence results of bacterial integrity. The cytoplasm of the epithelial cells was normal in the beginning, except that the mitochondrial matrix was heavily stained at all times and brought out the cristae in negative contrast (Figs 5, 7 and 8). One hour after infection, there were several bacteria in the cytoplasm of many cells, but in spite of this the ultrastructure of the cells was unaffected (Fig. 6). After 1 day, many cells containing bacteria started to degenerate. The first sign was dispersion of nuclear chromatin and re-organisation into fine granular aggregates that were not attached to nuclear envelope (Fig. 7). However, there were still structurally intact bacteria in the cytoplasm, but also inclusion bodies containing apparent bacterial structures, probably

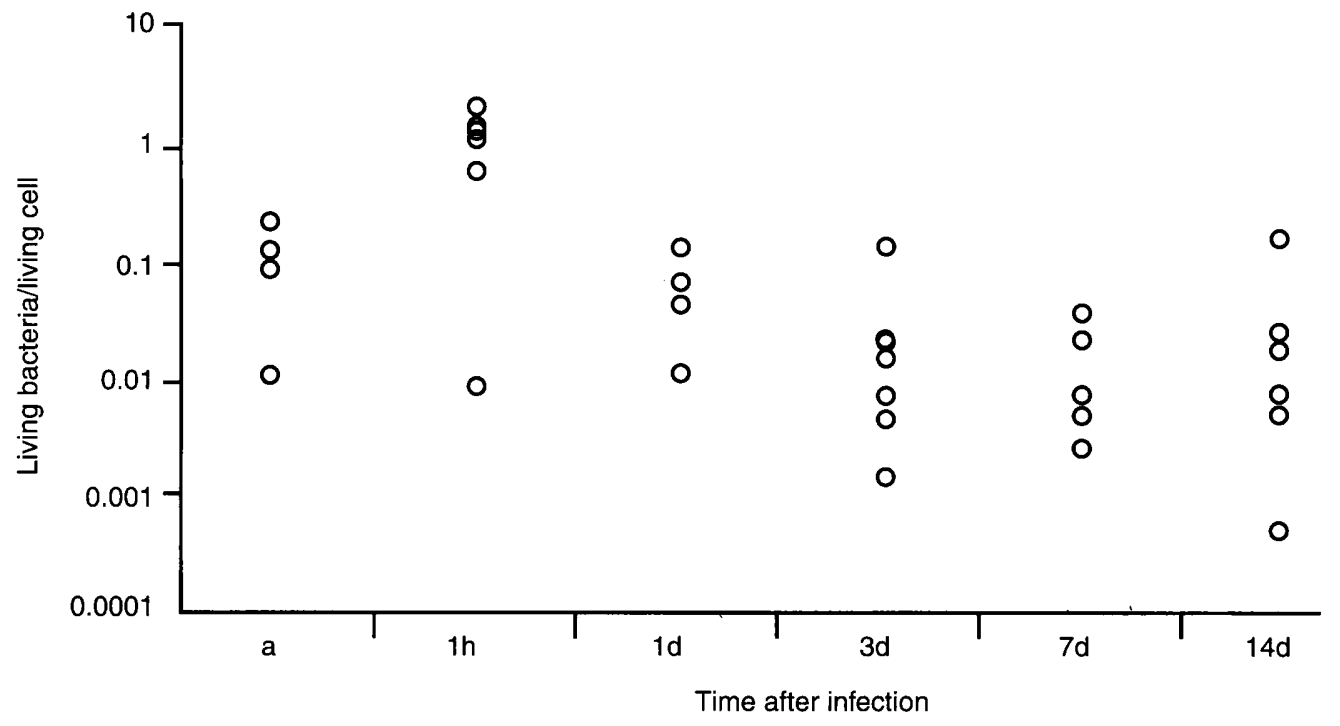

Fig. 1. The number of cfu/living cell after infecting Henle-407 cells with $S$. Enteritidis. Incubation was continued for different periods after infection as indicated in the figure; a, adhesion; d, day. Circles in each time point indicate results of different experiments; in each of them one flask was analysed. When the results of the later time points were compared with the results at $1 \mathrm{~h}$, the $\mathrm{p}$ values were 0.02 ( 1 day), 0.005 ( 3 days), 0.02 ( 7 days) and 0.005 (14 days). 

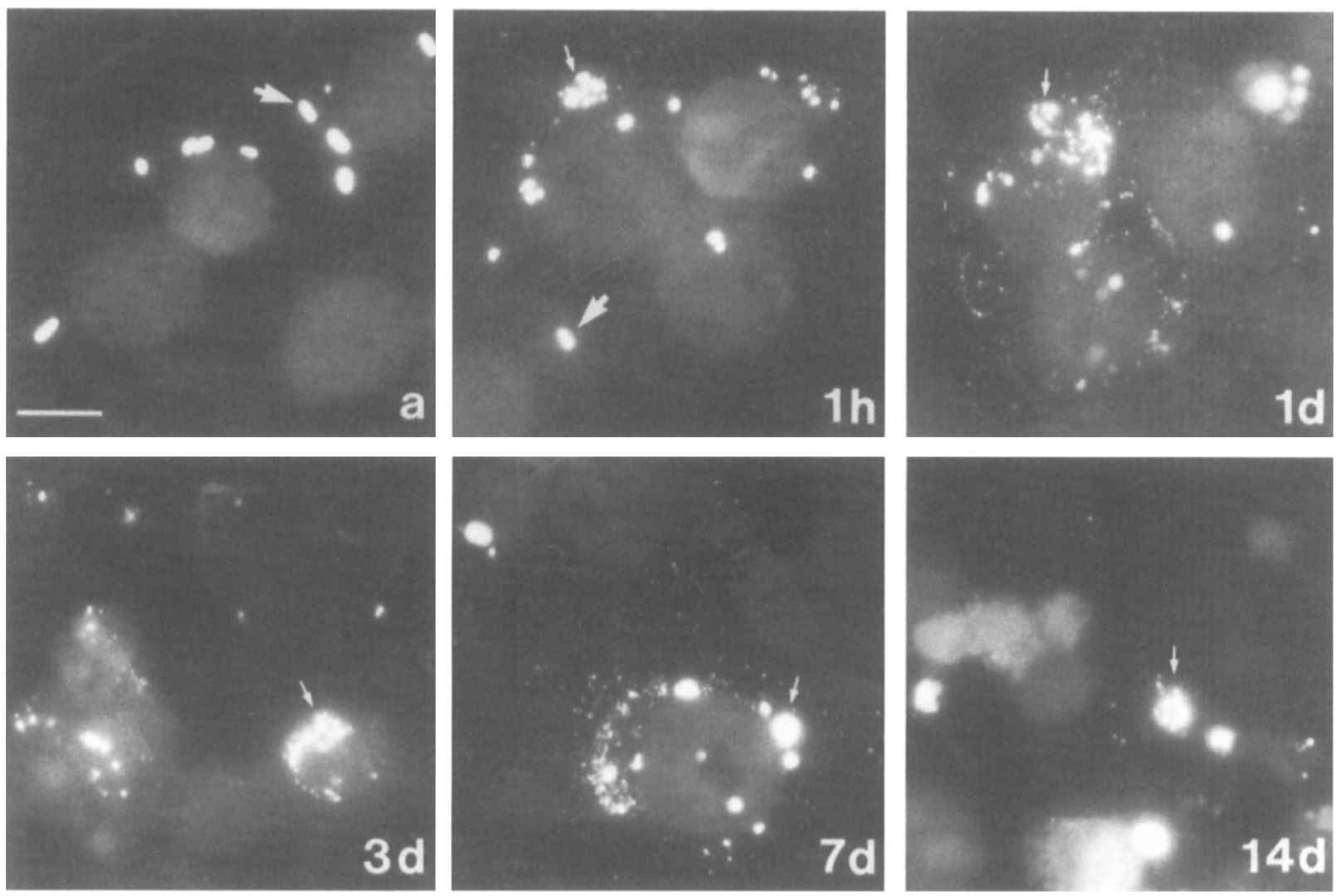

Fig. 2. Immunofluorescence localisation of bacterial structures in Henle-407 cells infected with $S$. Enteritidis. Incubation was continued for different periods after infection as indicated in the figure; a, adhesion; d, day. Large arrows indicate intact bacteria, small arrows indicate accumulations containing processed material. Bar $=4 \mu \mathrm{m}$.

processed polysaccharides. At 3 days, hardly any of the bacteria inside the cells were unaffected, and those which persisted had darkly stained uniform cytoplasm (Fig. 8). Each of the bacterial cells was first seen inside its own membranous vesicle, and later inside larger vesicles containing many bacteria.

\section{Discussion}

Host-microbe interaction is apparently abnormal in patients developing reactive arthritis as a consequence of salmonella or yersinia gastroenteritis. These bacteria or parts of them appear to persist in the body for a long time. In fact, bacterial antigens but not live bacteria have been detected in the inflamed joints and intestinal mucosa of patients suffering from reactive arthritis for years after the initial infection $[28,33]$. However, the exact pathogenesis of this non-purulent, asymmetric polyarthritis which develops to a chronic disease in some patients is still unclear. One important step in the pathogenesis of salmonella-triggered reactive arthritis is the primary invasion of bacteria into the host. The present study investigated more closely the interaction between salmonellae and intestinal epithelial cells, especially $S$. Enteritidis, because of its worldwide importance as a cause of reactive arthritis.

The observation that the number of intracellular bacteria was $c$. 10-fold higher than the number of bacteria attached to the cell surface may be explained by the long incubation time $(2 \mathrm{~h})$ of the cells and bacteria before the washing step. During this time the attachment sites at the cell surface may be occupied by the bacteria that cannot invade the cell; however, in those cells which bacteria can invade, the attachment sites become free again after the entry process, and new bacteria will have an opportunity to attach to the cell. It is also possible that during the incubation time of $1 \mathrm{~h}$ in gentamicin medium, the bacteria inside the cell start to multiply before the antibacterial mechanisms of the cell limit their number.

The finding of living bacteria inside cultured human intestinal epithelial cells by assay of cfu was confirmed by the electron microscopic demonstration of intact bacteria at the early time points. However, the majority of bacteria were degraded quite quickly. As epithelial cells are renewed every $2-5$ days in the intestine, one single cell cannot be the host of the bacteria for this entire period ( 2 weeks) in vivo. However, the survival of some bacteria inside the epithelial cells may provide a mechanism to overcome the problem of rapid cell turnover. By release from a dying cell and transfer to a living neighbouring cell bacteria would be able to persist in the intestine despite the rapid turnover of cells. Thus, intestinal epithelial cells could be one place where bacteria 


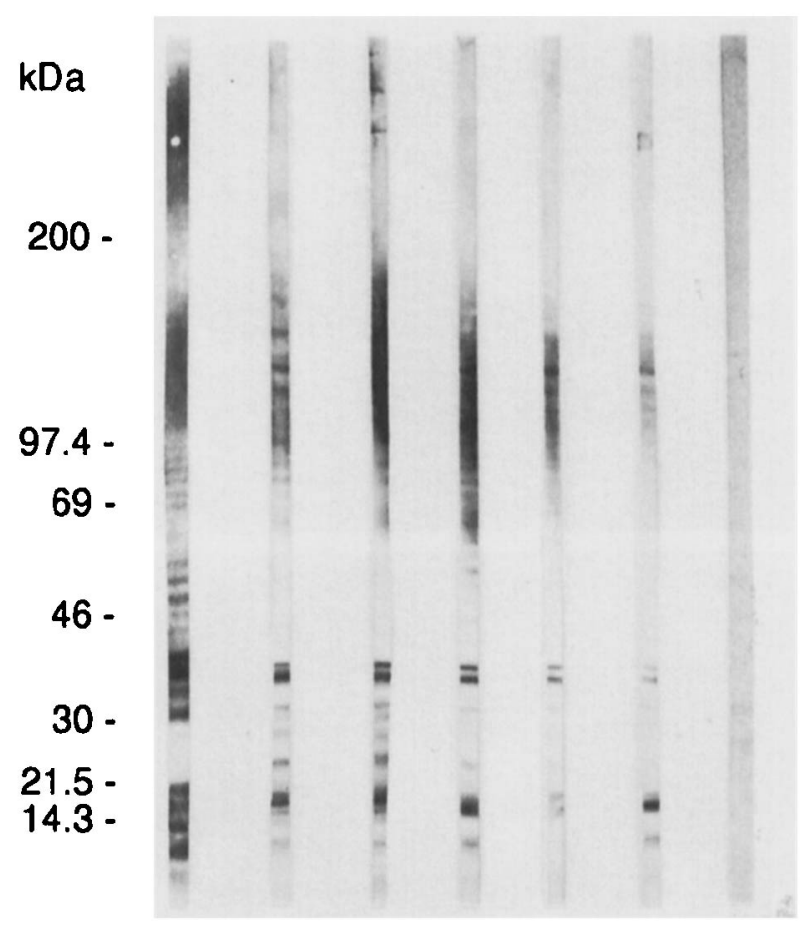

S.E. 1h 1d 3d $7 d$ 14d $\quad C$ Incubation times

Fig. 3. Western blot of $S$. Enteritidis (S.E.), uninfected control cells (C), and Henle-407 cells incubated for different periods after infecting with $\mathrm{S}$. Enteritidis (1 h14 days). Strips were treated with rabbit antiserum against $S$. Enteritidis.

persist in reactive arthritis patients, and eventually move from there to other parts of the host, in this case to the joints.

The finding of bacteria first inside individual vesicles and later in phagosomes containing several bacteria is in agreement with observations by other investigators

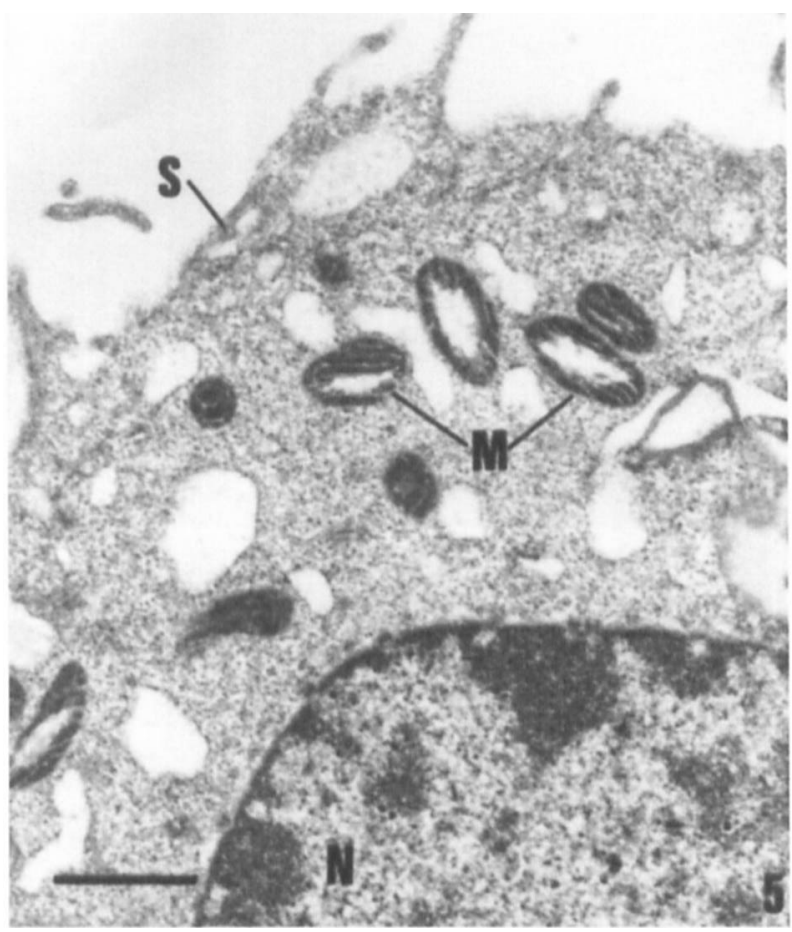

Fig. 5. Transmission electron micrograph of uninfected Henle-407 cell ( 3 days). M, mitochondria; N, nucleus; S, surface of the cell. Bar $=1 \mu \mathrm{m}$.

of $S$. Typhimurium in culture [34]. The possible lysosomal character of these vesicles requires further investigation, especially at the later time points, by immunolabelling electron microscopy. Another interesting finding by electron microscopy, which is worthy of further investigation, was the negative staining of mitochondrial matrix in infected as well as in control cells. This phenomenon probably reflects an unusual metabolic state in these cells.

Gentamicin has been commonly used in these kinds of studies to kill extracellular bacteria. Viable Listeria

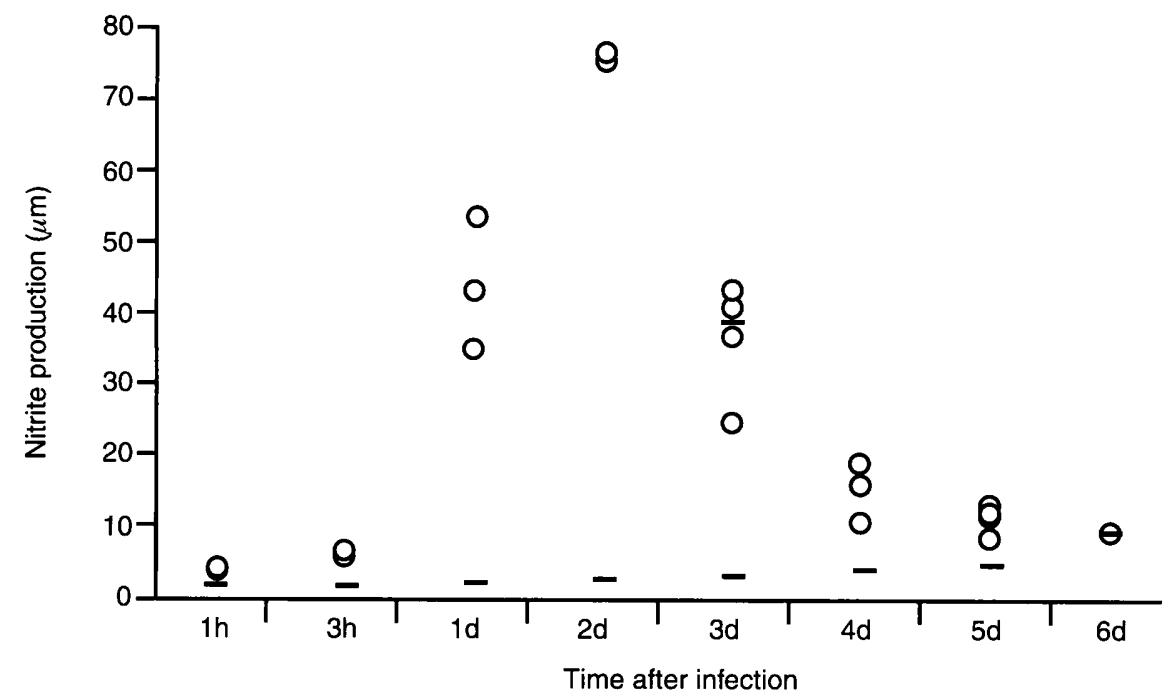

Fig. 4. Nitrite production by Henle-407 cells incubated for different periods after infection with $S$. Enteritidis $(1 \mathrm{~h}-14$ days). Circles indicate results of different experiments. Uninfected Henle-407 cells were used as controls. 


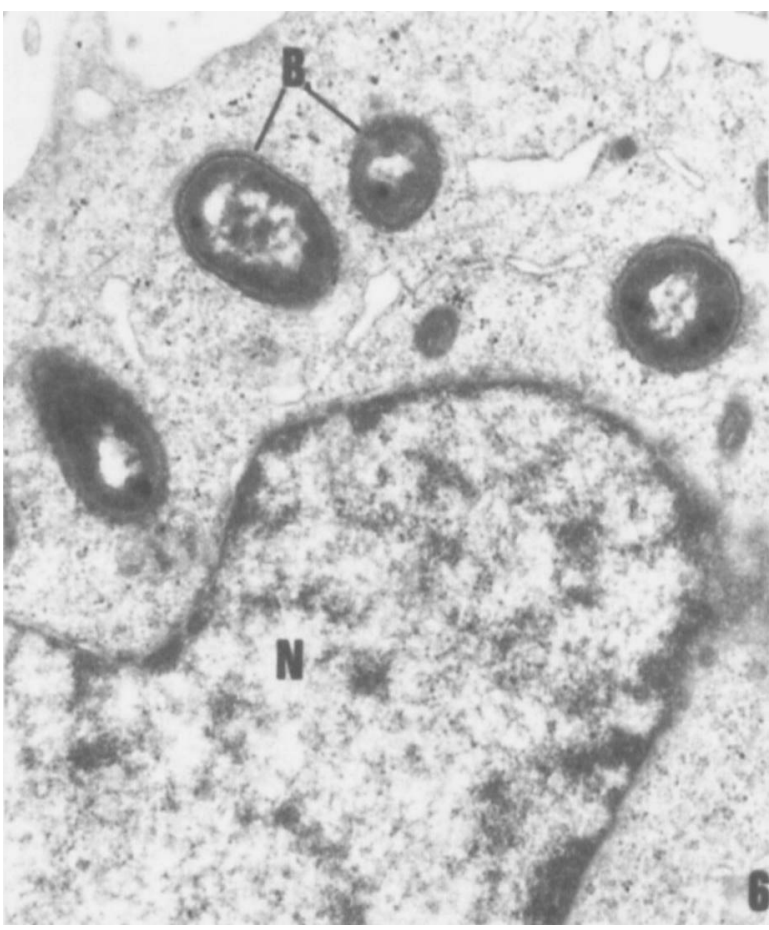

Fig. 6. Transmission electron micrograph of Henle-407 cell $1 \mathrm{~h}$ after infection with $S$. Enteritidis. B, bacteria; N, nucleus; $\mathrm{S}$, surface of the cell. Bar $=1 \mu \mathrm{m}$.

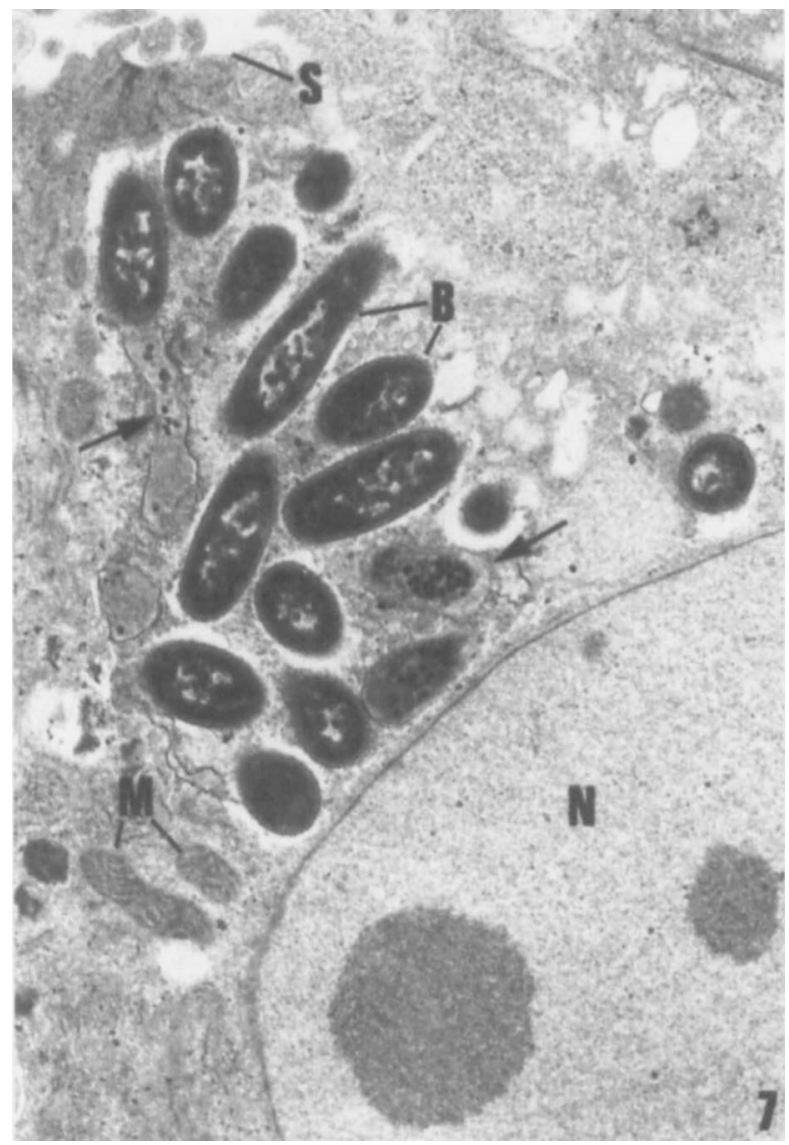

Fig. 7. Transmission electron micrograph of Henle-407 cell I day after infection with $S$. Enteritidis. B, bacteria; $\mathrm{M}$, mitochondria; $\mathrm{N}$, nucleus; $\mathrm{S}$, surface of the cell. Arrows indicate processed bacterial structures. $\mathrm{Bar}=1 \mu \mathrm{m}$

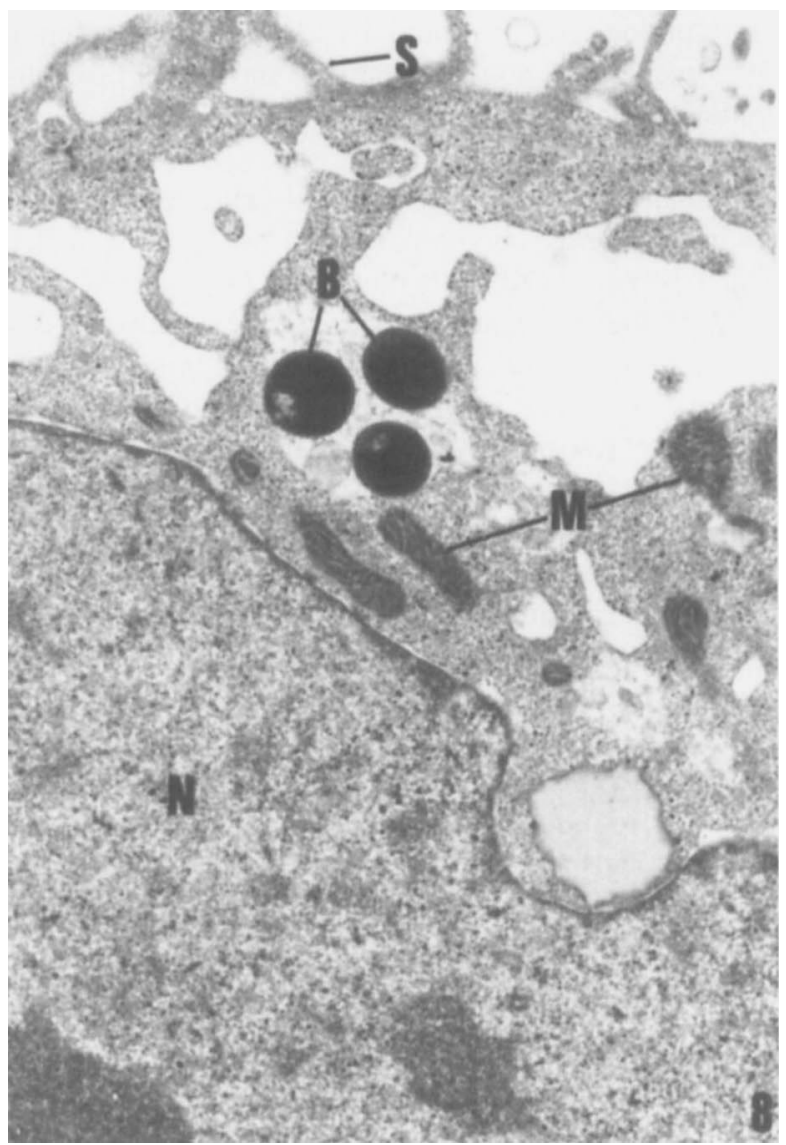

Fig. 8. Transmission electron micrograph of Henle-407 cell 3 days after infection with $S$. Enteritidis. B, bacteria; $\mathrm{M}$, mitochondria; $\mathrm{N}$, nucleus; $\mathrm{S}$, surface of the cell. Bar $=1 \mu \mathrm{m}$.

bacteria have recently been observed in mouse peritoneal macrophages [35]. However, it was noticed that although gentamicin is considered to be an antibiotic that cannot penetrate the cell membrane, macrophages pinocytose growth medium quite efficiently, which also brings gentamicin into the cell. This phenomenon increased the killing capacity of macrophages. Also, $S$. Typhimurium invasion into epithelial cells has been shown to induce formation of macropinosomes in the cells [36]. It is not known whether $S$. Enteritidis can cause a similar phenomenon in the cell line used in the present experiments, but if these cells pinocytose growth medium containing gentamicin, which helps kill bacteria inside them, it is probable that in vivo the bacteria stay alive longer in epithelial cells than in the study. On the other hand, in the case of $S$. Typhimurium, there were no bacteria inside the macropinosomes [36]. Thus, it is possible that in the epithelial cells, invading bacteria and pinocytosed extracellular fluid remain separately so that pinocytosed gentamicin would not get into the contact with the bacteria and would not affect the killing capacity of the cells. If, however, our hypothesis of the transfer of the bacteria from degrading cells to live neighbouring cells is true, the bacteria would be exposed to extracellular milieu for a 
short period, and it would be clinically important to test even the non-penetrating antibiotics for the eradication of bacteria from the intestine.

Intestinal epithelial cells infected with $S$. Enteritidis produced marked amounts of NO, an unstable radical which is associated with numerous phenomena in the body, including immune responses. The early increase in the production of NO until 2 days, and the subsequent steady decrease are probably correlated with the respective changes in the amounts of stimulating bacteria. The main purpose of the production of NO is probably killing the bacteria, but it could also explain some phenomena related to salmonella enteritis, for example, damage of intestinal epithelial cells [37] and abdominal pain. If the synovial cells in the joints produce $\mathrm{NO}$ in response to salmonella antigens, this could contribute to the inflammation seen in reactive arthritis.

Most patients with reactive arthritis are HLA-B27 positive. However, the exact role of HLA-B27 in the pathogenesis of reactive arthritis remains unclear. It seems that in HLA-B27 positive patients with reactive arthritis, the elimination of the bacteria is in some way inefficient. It is not known whether there is any difference in the capability of HLA-B27 positive and negative intestinal epithelial cells to process bacteria causing reactive arthritis. This could be one critical point in the pathogenesis of reactive arthritis, because epithelial cells form the first barrier against the bacteria on their way from the intestine further into the body. However, there are also other cell populations involved in microbe-host interaction in the intestinal environment in vivo; thus it could be worth studying these interactions more closely either in vivo or in vitro, for example, by using a phagocytic cell line with epithelial cells.

We thank Tiina Lähde, Sirpa From and Urpo Reunanen for skillfu technical assistance. This work was supported by grants from Sigrid Jusélius Foundation, the Academy of Finland, the Finnish Cultural Foundation, Juliana von Wendt Foundation, and by a contract with the Finnish Life and Pension Insurance Companies.

\section{References}

1. Hook WE. Salmonella species (including typhoid fever). In Mandell GL, Douglas RG, Bennett JE (eds) Principles and practice of infectious diseases. New York, Churchill Livingstone. 1990: 1700-1716.

2. Altmeyer RM, McNern JK, Bossio JC, Rosenshine I, Finlay BB, Galán JE. Cloning and molecular characterization of a gene involved in Salmonella adherence and invasion of cultured epithelial cells. Mol Microbiol 1993; 7: 89-98.

3. Elsinghorst EA, Baron LS, Kopecko DJ. Penetration of human intestinal epithelial cells by Salmonella: molecular cloning and expression of Salmonella typhi invasion determinants in Escherichia coli. Proc Natl Acad Sci USA 1989; 86: 51735177.

4. Finlay BB, Stambach MN, Francis $\mathrm{CL}$ et al. Identification and characterization of $\operatorname{Tn} p h o A$ mutants of Salmonella that are unable to pass through a polarized MDCK epithelial cell monolayer. Mol Microbiol 1988; 2: 757-766.

5. Galán JE, Curtiss R III. Cloning and molecular characterization of genes whose products allow Salmonella typhimurium to penetrate tissue culture cells. Proc Natl Acad Sci USA 1989; 86 6383-6387.

6. Lee CA, Jones BD, Falkow S. Identification of a Salmonella typhimurium invasion locus by selection for hyperinvasive mutants. Proc Natl Acad Sci USA 1992; 89: 1847-1851.

7. Ginocchio C, Pace J, Galán JE. Identification and molecular characterization of a Salmonella typhimurium gene involved in triggering the internalization of Salmonellae into cultured epithelial cells. Proc Natl Acad Sci USA 1992; 89: 5976-5980.

8. Finlay BB, Falkow S. Salmonella interactions with polarized human intestinal Caco-2 epithelial cells. J Infect Dis 1990; 162: 1096-1106

9. Francis CL, Ryan TA, Jones BD, Smith SJ, Falkow S. Ruffles induced by Salmonella and other stimuli direct macropinocytosis of bacteria. Nature 1993; 364: 639-642.

10. Ginocchio CC, Olmsted SB, Wells CL, Galán JE. Contact with epithelial cells induces the formation of surface appendages on Salmonella typhimurium. Cell 1994; 76: 717-724.

11. Zierler MK, Galán JE. Contact with cultural epithelial cells stimulates secretion of Salmonella typhimurium invasion protein InvJ. Infect Immun 1995; 63: 4024-4028.

12. Gahring LC, Heffron F, Finlay BB, Falkow S. Invasion and replication of Salmonella typhimurium in animal cells. Infect Immun 1990; 58: 443-448.

13. Leung KY, Ruschkowski SR, Finlay BB. Isolation and characterization of the $a d d A$ aminoglycoside-resistance gene from Salmonella choleraesuis. Mol Microbiol 1992; 6: $2453-$ 2460 .

14. Stenger $S$, Thüring $H$, Röllinghoff $M$, Bogdan $C$. Tissue expression of inducible nitric oxide synthase is closely associated with resistance to Leishmania major. $J$ Exp Med 1994; 180: 783-793.

15. Denis $M$. Interferon-gamma-treated murine macrophages inhibit growth of tubercle bacilli via the generation of reactive nitrogen intermediates. Cell Immunol 1991; 132: 150-157.

16. Rockett KA, Awburn MM, Cowden WB, Clark IA. Killing of Plasmodium falciparum in vitro by nitric oxide derivatives. Infect Immun 1991; 59: 3280-3283.

17. Ignarro LJ, Buga GM, Wood KS, Byrns RE, Chaudhuri G. Endothelium-derived relaxing factor produced and released from artery and vein is nitric oxide. Proc Natl Acad Sci USA 1987; 84: $9265-9269$

18. Zembala M, Siedlar M, Marcinkiewicz J, Pryjma J. Human monocytes are stimulated for nitric oxide release in vitro by some tumor cells but not by cytokines and lipopolysaccharide. Eur J Immunol 1994; 24: 435-439.

19. McCartney-Francis N, Allen JB, Mizel DE et al. Suppression of arthritis by an inhibitor of nitric oxide synthase. J Exp Med 1993; 178: 749-754.

20. Assreuy J, Cunha FQ, Epperlein $\mathrm{M}$ et al. Production of nitric oxide and superoxide by activated macrophages and killing of Leishmania major. Eur J Immunol 1994; 24: 672-676.

21. Middleton SJ, Shorthouse M, Hunter JO. Increased nitric oxide synthesis in ulcerative colitis. Lancet 1993; 341: 465-466.

22. Boughton-Smith NK, Evans SM, Hawkey CJ et al. Nitric oxide synthase activity in ulcerative colitis and Crohn's disease. Lancet 1993; 342: 338-340.

23. Lundberg JON, Farkas-Szallasi T, Weitzberg E et al. High nitric oxide production in human paranasal sinuses. Nat Med 1995; 1 : $370-373$.

24. Mäki-Ikola $\mathrm{O}$, Granfors $\mathrm{K}$. The bacteriology of reactive arthritis. Rev Med Microbiol 1993; 4: 144-150.

25. Inman RD, Chui B, Johnston MEA, Vas S, Falk J. HLA class Irelated impairment in IL-2 production and lymphocyte response to microbial antigens in reactive arthritis. J Immunol 1989; 142: 4256-4260

26. Mäki-Ikola O, Leirisalo-Repo $\mathrm{M}$, Kantele $\mathrm{A}$, Toivanen $\mathrm{P}$ Granfors K. Salmonella-specific antibodies in reactive arthritis. $J$ Infect Dis 1991; 164: 1141-1148.

27. Kusters JK, Mulders-Kremers GAWM, van Doornik CEM, van der Zeijst BAM. Effects of multiplicity of infection, bacterial protein synthesis, and growth phase on adhesion to and invasion of human cell lines by Salmonella typhimurium. Infect Immun 1993; 61: 5013-5020.

28. Granfors K, Jalkanen S, Lindberg AA et al. Salmonella lipopolysaccharide in synovial fluid cells from patients with 
reactive arthritis. Lancet 1990; 335: 685-688.

29. Laemmli UK. Cleavage of structural proteins during the assembly of the head of bacteriophage T4. Nature 1970; 227: 680-685.

30. Towbin H, Staehelin T, Gordon J. Electrophoretic transfer of proteins from polyacrylamide gels to nitrocellulose sheets: procedure and some applications. Proc Natl Acad Sci USA 1979; 76: $4350-4354$.

31. Salomonsen J, Skojdt K, Crone M, Simonsen M. The chicken erythrocyte-specific MHC antigen. Characterization and purification of the B-G antigen by monoclonal antibodies. Immunogenetics 1987 ; 25: 373-382.

32. Ding AH, Nathan CF, Stuehr DJ. Release of reactive nitrogen intermediates and reactive oxygen intermediates from mouse peritoneal macrophages. Comparison of activating cytokines and evidence for independent production. J Immunol 1988; 141:
2407-2412.

33. Hoogkamp-Korstanje J, de Koning J, Heesemann J. Persistence of Yersinia enterocolitica in man. Infection 1988; 16: 81-85.

34. Francis CL, Starnbach MN, Falkow S. Morphological and cytoskeletal changes in epithelial cells occur immediately upon interaction with Salmonella typhimurium grown under lowoxygen conditions. Mol Microbiol 1992; 6: 3077-3087.

35. Drevets DA, Canono BP, Leenen PJM, Campbell PA. Gentamicin kills intracellular Listeria monocytogenes. Infect Immun 1994; 62: 2222-2228.

36. Garcia-del Portillo F, Finlay BB. Salmonella invasion of nonphagocytic cells induces formation of macropinosomes in the host cell. Infect Immun 1994; 62: 4641-4645.

37. Tepperman BL, Brown JF, Whittle BJR. Nitric oxide synthase induction and intestinal epithelial cell viability in rats. $\mathrm{Am} \mathrm{J}$ Physiol 1993; 265: G214-218. 